\title{
IAMJ
}

INTERNATIONAL

AYURVEDIC

MEDICAL JOURNAL

ISSN: 2320-5091

Impact Factor: 6.719

\section{AYURVEDIC MANAGEMENT OF SCALP PSORIASIS WSR TO KITIBHA KUSHTHA - A CASE STUDY}

\author{
Ashwini Dravyekar ${ }^{1}$, Sunil Bhaskare ${ }^{2}$ \\ ${ }^{1}$ P.G. Scholar. Kayachikitsa Department, R.A. Podar Medical (Ayu) College, Worli, Mumbai-18., \\ Maharashtra, India \\ 2(M.D. PhD), Associate Professor, Kayachikitsa Department, R.A. Podar, Medical (Ayu) College, Worli, \\ Mumbai-18, Maharashtra, India
}

Corresponding Author: dravyekara@gmail.com

https://doi.org/10.46607/iamj5309102021

(Published Online: October 2021)

Open Access

(C) International Ayurvedic Medical Journal, India 2021

Article Received: 19/09//2021 - Peer Reviewed: 05/10/2021 - Accepted for Publication: 06/10/2021

Check for updates

\begin{abstract}
Background- Psoriasis is a chronic inflammatory condition. The age of onset, chronicity, a physical and psychological consequence of the disease cause psoriasis to have a significant impact on patient quality of life. Scalp Psoriasis is no different and effective treatment results in an improvement in quality of life. Aim- To study the efficacy of ayurvedic management of Scalp Psoriasis w.s.r to Kitibha Kushtha. Methodology- This study deals with a 45-year-old female patient having complaints of itching over the scalp region, powdery discharge from that region, burning present over that region for 2 years. The patient was diagnosed with Scalp Psoriasis as per modern and Kitibha Kushtha as per Ayurveda. Result- The patient got symptomatic relief in Scalp Psoriasis at the end of treatment. Conclusion- Ayurvedic management was found to be effective in Scalp Psoriasis.
\end{abstract}

Keywords: Kitibha, Kushtha, Scalp Psoriasis. 


\section{INTRODUCTION}

Psoriasis is a chronic, recurrent inflammatory disease of the skin characterised by well-circumscribed erythematous, dry plaques of various sizes covered with mica like scales. ${ }^{1}$ Scalp Psoriasis has asymptomatic plaques with thick silvery scales that tend to extend beyond scalp margines. ${ }^{2}$ Scaling may be massive especially in the occiput may spread to the forehead and nape of the neck. ${ }^{3}$ The estimated incidence of scalp Psoriasis is $45-60 \% .^{4}$ Lesions appear at the site of skin trauma such as scratches or surgical wounds called as Kobners Isomorphic phenomenon. ${ }^{5}$ On scrapping psoriatic lesion with a microscopic slide silvery scales come out first. After that pinpoint bleeding comes out at the base of the lesion. This is known as the Auspitz sign. All the skin diseases in Ayurveda are divided into Maha Kushtha and Kshudra Kushtha. Kitibha Kushtha is considered under Kshudra Kushtha. Kitibha Kushtha has lakshanas like shyava, kina khara sparsha, purulent, ruksha Pidika and Kandu. Due to vitiation of Spatha dhatus like three doshas, Twaka, Rakta Mamsa, and Lasika Kitibha Kushtha develops ${ }^{6}$.It also includes the involvement of Vata and Kapha dosha. ${ }^{7}$ Kitibha means Shyava (silvery scaly lesion), Kina Khara sparsha (hard), Parushya (rough to touch) ${ }^{8}$

\section{PATHOPHYSIOLOGY}

The main abnormality in psoriasis is increased epidermal proliferation due to excessive divisions of cells in the stratum basalae and a shorter cell cycle. In association with basal cell hyperplasia there is enhanced metabolism and accelerated synthesis and degradation of nucleoproteins, resulting in hyperuricemia lymphocytes are important in the pathogenesis. $^{9}$

Nidan sevana like Aharaj, Viharaja and Mansik hetu, Spicy food, Junk food, exposure to cold air resulting in Tridosha dushti as well as, Twak, Rakta, Mamsa Lasika dushti. Because of all this sthanasamsraya is present over Twacha, Kandu and Pidika occurs over the scalp resulting in scalp Psoriasis. ${ }^{10}$

\section{CASE STUDY-}

A 45-year-old female patient came to OPD with complaints of severe itching and burning sensation at the scalp region and powdery scales from that region. No history of Diabetes and Hypertension and other habits. No history of such a condition was observed in the family. No incidence of contact with any topical irritant. The patient had visited a dermatologist and was diagnosed with Scalp Psoriasis before 1 year but did not get sustained and satisfactory results.

On examination skin lesions were dry, silvery scales over the scalp, severe itching and powdery discharge was found.

Laboratory Investigation- Blood routine -Normal, Rest other system findings also normal.

Systemic Examination-CVS - S1S2 normal, CNSconscious and oriented

\section{> SAMPRAPTI GHATAKA-}

- Dosha-Tridosha

- Dushya-Twak, Rakta, Mamsa, Lasika

- Ama-Jatharagnijanya ama

- Agni-Jatharagnijanya

- Strotas-Rasavaha, Raktavaha

- Strotodushti Pravara-Sanga

- Rogamarga-Bahya

- Udbhava sthana-Amashaya

- Vyatka Sthana-Twacha

- Roga Swabhava-Chirakari

- Sadhyaasadhyta-Sadhya.

$>$ TREATMENT GIVEN

- Gandhak Rasayana 1 tablet twice a day

- Kaishor Guggulu 2 tablets twice a day.

- Arogyavardini Vati 2 tablets twice a day

- Haritaki Churna $3 \mathrm{gm}$ at bedtime.

- Khadirarista $20 \mathrm{ml}$ twice a day

- Panchatikta Ghrita for Local application.

$>$ ASSESSMENT OF CLINICAL FEATURES BASED ON GRADATION SYSTEM

\section{Shyavam}

- Normal Skin tone -0

- Mild brownish discolouration -1

- Moderate brownish discolouration 2

- Severe brownish discolouration 3.

\section{Kinkara Sparsha}

- Normal Skin tone 0 
- Mild rough lesions on touch 1

- Moderate rough lesions on touch 2

- Severe rough lesions on touch with scaling -3

3. Parushtwa-

- Normal Skin-0

- The mild hardness of lesion 1

- The moderate hardness of lesion 2

- Severe Hardness of lesion with Scaling -3

4. Kandu-

- No itching 0
- Mild /occasional localised itching which is tolerable -1

- Moderate generalised itching 2

- Very severe itching disturbing sleep and other activity -3

\section{$>$ RESULT AND DISCUSSION}

After starting the treatment symptoms were decreased in one month in 3 months patient showed significant improvement.

ASSESSMENT OF RESULT

\begin{tabular}{|l|l|l|}
\hline SYMPTOMS & Before Treatment & After Treatment \\
\hline Shyava & 2 & 1 \\
\hline Kinakharasparsha & 3 & 0 \\
\hline Parushyatwa & 3 & 0 \\
\hline Kandu & 3 & 1 \\
\hline
\end{tabular}

$>$ CLINICAL IMAGES BEFORE AND AFTER TREATMENT

Before Treatment
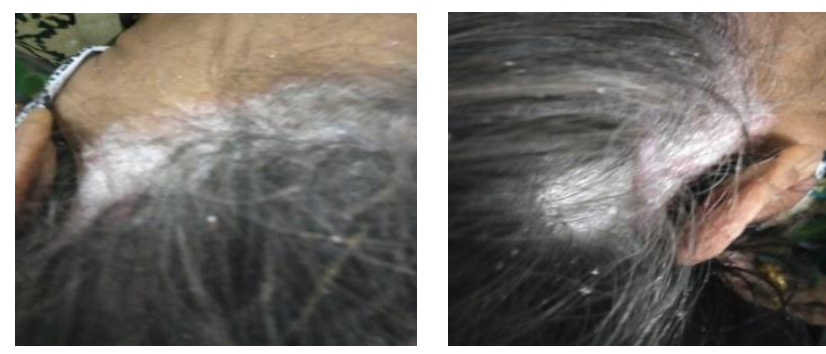

After Treatment
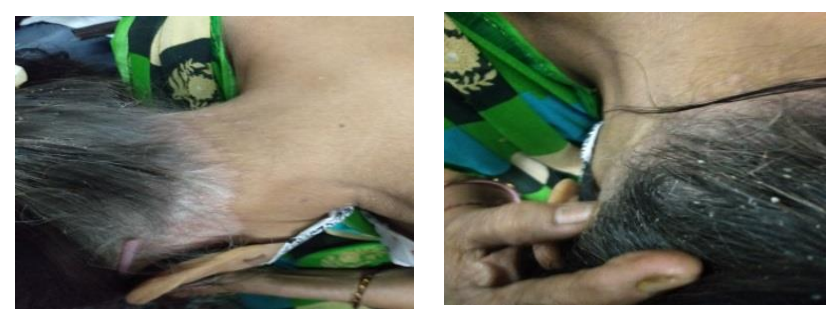

\section{DISCUSSION}

Here Deepan Pachana was initially done with Amapachana dravyas like Arogyavardini Vati ${ }^{11,12}$ and anulomana was given like Haritaki Churna. Gandhak Rasayana is useful in burning sensation as a patient have burning sensation, it is also useful in itching, it is also Rasayana and Kushthaghna. It acts on Skin and Rakta. It helps in the purification of blood. ${ }^{11}$ Khadirarishtha also called Sarva Kushthanivaraka by Bhaishajya Ratnavali. Khadirarista specifically acts on Lasika and inhibits the jivanus of kushtha. ${ }^{13,11 .}$ As the patient have itching and burning to relieve burning ghrita was given, as ghrita is specifically used for the treatment of pitta, burning means there is a predominance of pitta dosha and here Panchatikta ghrita helps in relieving scaling and healing. It is useful in Dushti Vrana, Krimijanya roga. ${ }^{14}$

\section{CONCLUSION}

The ayurvedic management given in Psoriasis showed significant improvement. This was a case study where multiple ayurvedic medicines were given and local applications used, which gave relief to the patient symptomatically. But still, further study is needed for more evaluation.

\section{REFERENCES}

1. Aspi.F. Golwala; Medicine for Students; $24^{\text {th }}$ edition; page no.721.

2. Uday Khopkar; Skin and Sexually Transmitted diseases; seventh edition; page no.137.

3. Aspi.F. Golwala; Medicine for Students; $24^{\text {th }}$ edition; page no.722. 
4. Merola JF, Li. T, Li, Wet. al. Prevalence of Psoriasis phenotypes among men and women in the USA. CLIN Exp Dermatol.2016;41;486-489. [PMC free article] [Pub Med] [Google Scholar]

5. Davidson's principle and Practice of Medicine; $23^{\text {rd }}$ edition, page no 1248.

6. Harishchandra Singh Kushwaha; Charak Samhita by Acharya Charaka; Chakrapanidatta virachita Ayurveda deepika tika Hindi Vyakhya; Chaukhamba Prakashan; edition 2018; Volume2; Chikitsasthan 7/9-10 page.no.197.

7. Harishchandra Singh Kushwaha; Charak Samhita by Acharya Charaka; Chakrapanidatta virachita Ayurveda deepika tika Hindi Vyakhya; Chaukhamba Prakashan; edition 2018; Volume2; Chikitsasthan 7/29 page.no.199.

8. Harishchandra Singh Kushwaha; Charak Samhita by Acharya Charaka; Chakrapanidatta virachita Ayurveda deepika tika Hindi Vyakhya; Chaukhamba Prakashan; edition 2018; Volume2; Chikitsasthan 7/22page.no.198.

9. K. George Mathew; Praveen Agrawal; Medicine Preparation Manual for Undergraduates; reprinted edition 2017, chapter 4; page no.300.

10. Sharma R. K. Dash. B. English Translation on Charak Samhita of Agnivesha; Reprint 2014; Chikitsastahn; Kushthachikitsa; Chapter 5 Verse 4; Varanasi (India); Chaukhamba Sanskrit Series Office,2014, page.no.68.

11. Vaidya Gangadhar Shastri; Ayurvediya Aushadi Guna dharma Shastra; Chaukhamba Prakashan; page no.80.75,27,

12. Rasa Vagbhata, Ras Ratna Samucchaya; $7^{\text {th }}$ edition; 20th chapter Shloka 87-93, Commentary by Ambika Datta Shastri, chaukhamba Sanskrit Series; Varanasi. Page no.400.

13. Acharya Sharangdhara, Sharangdhara Samhita Madhyama khanda 10/60-65annoted with Dipika Hindi Commentary narrated by Dr. Brahmanand Tripathi, Chaukhamba Surabharati Prakashan, reprint 2008, 9/1.page no.249.

14. Ambikadatta Shastri; Bhaishajya Ratnavali; Vidyotini Hindi Vyakhya; Chaukhamba Sanskrit Samsthana; reprint edition, 2004; Kushtharogachikitsaprakaranam $54 / 259,260$.

\section{Source of Support: Nil \\ Conflict of Interest: None Declared}

How to cite this URL: Ashwini Dravyekar \&L Sunil Bhaskare: Ayurvedic Management of Scalp Psoriasis Wsr To Kitibha Kushtha -A Case Study. International Ayurvedic Medical Journal \{online\} 2021 \{cited October 2021\} Available from: http://www.iamj.in/posts/images/upload/2615 2618.pdf 